\title{
Dialectical Moralism, National Interest, and Foreign Policy: The Case of United States and Pakistan
}

\author{
Muhammad Nadeem Mirza ${ }^{1}$ and Summar Iqbal Babar $^{2} *$
}

\begin{abstract}
US foreign policy throughout the history is replete with the moralistic rhetoric - pursuance of American moral principles embodied in the declaration of independence, constitution, and in the repeated doctrines of the American presidents. Yet the careful examination of its foreign policy reveals that it remained mostly amoral in nature, that is, devoid of any moral or immoral essence. It has mostly pursued the national self-interest which remained dynamic because of the changing geopolitical environment of the region and the world. Use of religion since Pakistan's independence to align with it against godless communist Soviet Union, neglecting Pakistan's nuclear program because of the greater national self-interest during 1980s, supporting military governments in Pakistan while being the biggest proponent of democracy in the world, use of drone warfare while violating the sovereignty and international law, are few of the amoralistic policies being pursued by the United States towards Pakistan. The study concludes that the United States have/will continue to use the moral rhetoric as a leverage to pressurise or entice Pakistan to do its bidding and in the case of failing, to utilise the same rhetoric as a tool to distance itself from Pakistan, when its national interests are served.
\end{abstract}

Keywords: Universal moral principles; Realism; Melian Dialogue; United States; Pakistan.

\section{Introduction}

United States foreign policy throughout the history is replete with dialectical positions about the role of morality in the processes involving states. This conflict in their foreign policy discourse is best described by National Security Advisor Brzezinski to President Carter in these words, "In world politics nothing succeeds like success, whatever the moral aspects" (Brzezinski, 1979). This paper argues that, although these are the moral principles that are being espoused by the United States, yet American foreign policy generally, and towards Pakistan specifically, is amoralistic in nature - that is devoid of any moral or immoral essence. It further highlights the point that states generally, and great powers specifically, pursue the policies clothed in moralism so as to achieve the national self-interest. US leaders throughout the history - such as

${ }^{1}$ School of Politics and International Relations, Quaid-i-Azam University Islamabad, Pakistan.

${ }^{2}$ School of Politics and International Relations, Quaid-i-Azam University Islamabad, Pakistan.

*)Corresponding Author.

Email: summar.rao@qau.edu.pk 
George Washington, John Quincy Adam, Woodrow Wilson, Theodore and F.D Roosevelt, Truman, Reagan, Bush Sr., Clinton, Bush Jr. or Obama - have used the moral principles to expand the 'veiled self-interest' of the United States, as prescribed by the realists (Mirza, 2016). Morgenthau notes that every state pursues its national interest, and for that it "clothes (its) own particular aspirations and actions in the moral purposes of the universes" (Hans J. Morgenthau, as cited in Meernik, 2004, p. 119). National interest guided policies of the United States through most of its history, instead of the moral principles. Josef Joffe points out that "American foreign policy since 1945 has followed interests rather than ideology, and so the former will outlive the latter" (Joffe, 1992, p. 33).

\section{Theoretical Construct: Amoralism in the case of States}

The question involved here is not that whether the policies adopted by the states are right or wrong, have positive or disastrous consequences, it is that whether objectives determined by the national interest are achieved or not. Power plays consequential role in determining objectives, distilling policy options, and even defining issue areas. "In international affairs, behind all questions of morality lie questions of power" (Kaplan, 2011). Realists, such as Morgenthau, termed states' belief in moral principles as a fallacy and consider that state "in the blindness of crusading frenzy, destroys nations and civilizations - in the name of moral principles, ideals, or god himself" (Hans J. Morgenthau, as cited in Frost, 2012, p. 22). He presented the point of view of E.H. Carr on the issue in these words; morality is "an escape from the logical consequences of realism, which, once it is achieved, must once more be attacked with instruments of realism" (Morgenthau, 1948, p. 134). Athenians at one point during the Melian Dialogue, written by Thucydides, exclaimed, "You seem to forget that if one follows one's self-interest one wants to be safe, whereas the path of justice and honour involves one in danger" (Thucydides, 1840). Similarly Carr noted, the "justice is the right of the stronger" (Carr, 1964). It depicts that moralism, justice, and other such principles suit only to the individuals living in a hierarchical domestic structure of the state. Most of the realists are of the view that these notions are detrimental in an international system which is Hobbesian and anarchic in nature.

An important issue attached with moralism is the role of religion in states' interactions - especially the role played by evangelicals, and other rightist elements in the foreign policy formulation process. Generally realists reject the role of states' religion in international affairs considering them to be like units which are "closed, impermeable and sovereign" (Mirza, 2016, pp. 168-169). Neoclassical realists challenge this assertion and have introduced certain "intervening variables" which act as the 'transmission belt' between the systemic pressures and the state's external behaviour (Ripsman, Taliaferro, \& Lobell, 2016; Siddiqi \& Mirza, 2021). religion, thus, act as an important intervening variable affecting the state's foreign policies, but they again 
approve the role of religion only when it enhances the interests of the states. An example from the history is the Athenians behaviour who in response to the Melos' warning to them of the gods' fear declared that "so far as the favour of the gods is concerned. We think we have as much right to that as you have." In other words they challenged the Melos' warning and used the notion of the help from gods in their national self-interest and ultimately forced the Melos to submit (Thucydides, 1840).

Similarly, scholars associated with raison d'état are of the view that the states have the authority and right to behave in a manner which is unacceptable for the individuals. For the states there exist "dual moral standard: one for individual citizens living inside the state and a different standard for the state in its external relations with other states" (Dunne, Brian, \& Schmidt, 2011, pp. 86-87). It has the authority to use violence against criminals or those challenging its authority. This whole debate is based upon the Weberian conception of state having 'monopoly over legitimate means of violence' (Dusza, 1989; Hanke, Scaff, \& Whimster, 2020). The state has emerged, since the Westphalian Order, as a moral authority in itself. Realists are not outrightly against moralism. They believe that 'state itself represents a moral force' hence it is "kind to be cruel" in the pursuance of its self-interest (Desch, 2003, pp. 415-426). Realists thus profess that states should not pursue the moralistic foreign policy, but at the same time they do not profess a total neglect of moralism. Martin Griffith commented on the ideas of E.H. Carr as "although he (Carr) was a severe critic of utopian thinking in the 1930s and 1940s, he also acknowledged that realism without utopianism could descend into a cynical realpolitik." (Carr, 1999, p. 8). They suggest pursuing policies based on amoralism with the objective of pursuing a 'tamed' national selfinterest (Mirza, 2014, 2016).

\section{US Capitalization of the Universal Moral Principles}

The United States had developed its ideological position around universal moral principles. It has been ascribed the title of the "torch-bearer of the democracy" (Eales, 2015). But the fact remains that the US - being the great power in the international system - has effectively capitalised on these principles in order to enhance its geopolitical interests in the world (Dunne \& Schmidt, 2001, p. 179; Mirza, 2016). Elshtain notes, "If you look at the United States, you can see that very clearly - whether it's the World War I era or the World War II era, even Vietnam and certainly Iraq. You have the articulation of certain moral norms, very high ideals that are considered to be or are claimed to be in play" (Elshtain, 2009). In fact the American Mission to defend and promote democratic ideals in the world is defined on the basis of "moralism, legalism, and idealism" (Ohaegbulam, 1999, p. 72). Realists pronounce that these traditions act as the necessary tool for the pursuance of the national self-interest, e.g., President Wilson may be remembered as one of the most anti-imperialist and staunch supporter of the democracy at home and abroad. Yet he was also the one who had authorised the use of force "seven 
times" (Chambers \& Anderson, 1999, p. 807) against other states during his era - twice in Mexico, once in Haiti, in the Dominican Republic, in World War I, in northern Russia, and in Siberia.

Historically Vietnam presented one of the best examples of the American amoralism in action. The United States did not care that whether their actions in South East Asia were legal, moral, or immoral. They simply tried to achieve their targets by using all the possible means - even if the means were too malevolent. Declassified documents revealed that on December 9, 1970, during the Vietnam War, President Nixon gave orders to Henry Kissinger in these words: "I want them to hit everything, I want them to use the big planes, the small planes, everything they can that will help out there, and let's start giving them a little shock" (Kissinger \& Nixon, 1970), Kissinger immediately called General Alexander Haig and relayed the president's orders as: "He wants a massive bombing campaign in Cambodia. He doesn't want to hear anything. It's an order, it's to be done. Anything that flies, on anything that moves. You got that?" (Kissinger \& Haig, 1970). The result was the massive US bombing campaign against Cambodia and Vietnam. In the case of Cambodia alone, from 1965 to 1973, the United States dropped about " $2,756,941$ tons of ordnance, in 230,516 sorties on 113,716 sites." Ironically "just over 10 percent of this bombing was indiscriminate, with 3,580 of the sites listed as having 'unknown' targets and another 8,238 sites having no target listed at all" (Owen \& Kiernan, 2006, pp. 62-69). Thousands - both combatants and non-combatants - died because of this campaign. Millions more died as a consequence of this campaign - for example Khmer Rouge in Cambodia exploited the bombing campaign for recruitment and strengthening of its position, and within a few years it took over the capital and launched cultural restructuring programs which resulted in a massive genocide (Model, 2008, p. 67; Morris, 2015).

Attacks of September 11 opened a new Pandora box and the United States took certain steps - with regard to Pakistan specifically and in the world generally - that are remotely connected with the moralistic precincts. It launched unprecedented attacks on Afghanistan and Iraq, besides launching Global War on Terrorism, using which it would intervene in any part of the world, anytime (Bush, 2001a, 2001b, 2002). Cluster bombing, drones, predators, B-52 bombers, black sites, torture flights, Black-Water, became the daily used terms. Following the norms of the international society the enemies were designated "as aliens and sub-humans thus justifying their (torture and) slaughter" (Ferguson, 2007, p. xxxiv). Scholars have pointed out that the United States in the course of its war on terror has "again proved inconsistent with its own principles in dealing with terrorist suspects and political detainees" (Chew, 2009, pp. 134-135). President Bush after being bestowed with extraordinary powers by the Congress (Senate Joint Resolution-23 passed on September 14, 2001) - besides attacking Afghanistan and Iraq - authorised the detention, torture, and killing of the militants at home and abroad. One of the examples is his administration was authorisation of water-boarding, 
"which in the view of almost all experts clearly passes the severe pain threshold in the definition of torture in international law" (Geoffrey Robertson, as cited in Hawley, 2010). One member of Bush administration, Jack Goldsmith - an assistant attorney general in the George W. Bush administration - once mentioned, "military detention was once legally controversial but now is not" (Goldsmith, 2010). Critics argued that those militants were taken from one secret militant international network (Al Qaeda) to another international hidden network of secret prisons and interrogation centres managed by American intelligence agencies (Danner, 2009). These actions lowered the American moral standing not only in the world, but also among the America's closest allies. When certain European countries learnt the fact that American intelligence agencies have long maintained 'black sites' in Europe and that the United States had flown several militants from there with or without their notice - they were infuriated and demanded immediate closure of such sites (Council of Europe, 2008, p. 34). One German intelligence officer mentioned such behaviour of the CIA as comparable to 'Serbian war criminals during the breakup of Yugoslavia. "The Serbs ended up before the international court in The Hague for this kind of thing" (Paterson, 2006). America's behaviour in such situation is best depicted by the statement of a CIA official, "if you don't violate someone's human rights some of the time, you probably aren't doing your job" (Priest \& Gellman, 2002). With such a frame of mind the American amoralism climaxed and moralism degenerated. President Obama won the election promising that he will try to clear the tarnished image of the United States. But he failed to close Guantanamo Bay Prison and torture continued - though through different means. During his era, the defence budget increased, the American military's involvement in the world enhanced many-fold. He "once promised to restrict the national security state put in place after 9/11. Instead he has expanded its ... operation" (Madar, 2012). Similarly, President Trump's four years in White House and his 'America First' approach has estranged allies and foes alike. United States has shelved exceptionalism and has started behaving like a normal state which is content in its border and which is no more interested in the spread of democracy, or uplifting moralism throughout the world (Patrick, 2019). Nor United States will share the burdens other states. Those who are relying upon the United States are suckers and have leeched the United States. No more, declared President Trump, and the United States will be a champion of not others, but of its own. Whether it is domestic politics or international, Trump has shown his wariness towards moral principles (Harwood, 2017).

\section{Amoralism and Foreign Policy in the case of United States and Pakistan,}

US foreign policy towards Pakistan can best be explained by this statement of former President Obama: "I refuse to set goals that go beyond our responsibility, our means, or our interests" (Obama, 2009). The statement clearly depicts that Americans are not Afghanistan - neither had they ever 
been in the past - to help Pakistan or Afghanistan; indeed, they are here because this is the demand of their national interest. Moralism might appear in the rhetoric, but amoralistic approach makes United States to not pursue a 'uniform' policy towards Pakistan. It considers that policies are not the inviolable laws, they get changed, sometime drastically and sometimes through evolutionary process, according to the dynamic national interest involved. Mile Copeland - a former CIA officer - once noted, "when we chose to violate any of our policies, from being truthful in our diplomacy to refraining from 'interfering in internal affairs of a sovereign nation' we (always) find means outside the normal machinery of the government" (Copeland, 1970, p. 12).

US foreign policy towards Pakistan can also be termed as 'exceptional' because it is a blend of two seemingly opposing characteristics: isolationism and moralism. Isolationism has dictated the United States to refrain, while moralism has provided it the rationale to interfere in the domestic affairs of Pakistan. It is the regional and international geopolitical environment and the endemic security challenges emanating from the region (Mirza, 2014) that has dragged the United States to the region, time and again. Former President Obama stated at Chicago Council in 2006, even before his nomination for the presidency: US needs "a strategy no longer driven by ideology and politics but one that is based on a realistic assessment of the sobering facts on the ground and our interests in the region" (Obama, 2006). Following are few of the examples depicting the US amoralistic policies towards Pakistan.

\subsection{Religion as a Tool of Foreign Policy}

During Cold War United States had used links between Christianity and Islam as a tool to instigate 'Muslim' Pakistan against the 'god-less' communists of the Soviet Union. Pakistan responded positively and its first Prime Minister Liaquat Ali Khan on his visit to the United States highlighted the similarities between the two religions thus presenting a case for the natural alignment between the two (Khan, 2014). Pakistan presented a unique opportunity to act as a bridge with the Muslim world (US Department of State, 1950). Cold War dynamics had forced it to enlist maximum number of allies, and Pakistan being the biggest Muslim state in the world at the time - could help it in this regard (Rizwan Hussain, 2005, p. 68). US support for the Afghan Jihad during 1980s is another such example. Muslims sentiments were flamed throughout the world against the atrocities being committed by the Soviet supported government at Kabul and guerrilla training was imparted to the Mujahideen. In fact the United States was simply responding to the dictates of its national interest which in the words of National Security Advisor Zbigniew Brzezinski was to make Afghanistan, a 'Soviet Vietnam' (Nelson, 2008, p. 109). The United States had started supporting Afghan Mujahideen even before the Soviet invasion of Afghanistan under CIA-sponsored Operation Cyclone (Billard Jr, 2010; Williams, 2011). After achieving its immediate national interest of defeating Soviet Union, United States pursuing the dictates of the 
amoralism left Afghanistan and attached problems for Pakistan to deal with. But the policies adopted by the United States during 1980s created a backlash in the later decades in the form of a well-trained and well-armed guerrilla force challenging not only the regional stability but also threatening the American interests in the world.

\subsection{Nuclear Issue}

Before the Soviet invasion of Afghanistan, the United States had severed most of the economic and military links with Pakistan, citing its pursuance of the nuclear program. As soon as Afghan Jihad started, using amoralistic policies the United States side-lined the nuclear issue of Pakistan. Brzezinski, while informing Secretary of State Vance about Presidential decision in response to the Soviet invasion, noted "we ... urge the Pakistanis to put the (nuclear) problem aside for solution later while we deal with the Soviet-Afghan problem" (Brzezinski, 1980). Throughout the 1980s, despite repeated warning by the intelligence community about developments in the Pakistan's nuclear program, the United States brushed aside the issue to be dealt at a later stage. The US Congress passed the Pressler Amendment demanding the president to certify on yearly basis that Pakistan is neither having the nuclear devices, nor it is developing one (Mahmood, 1994). Although the declassified official documents reveal that the US Defense Intelligence Agency had informed Reagan administration in October 1985 that Pakistan had developed nuclear weapons' capability (Defense Intelligence Agency, 1985), yet President Regan continued to 'lie' and provide this certificate to the Congress. As soon as the Soviets were out of Afghanistan, sanctions were imposed on Pakistan.

\subsection{Democracy Promotion}

Former Ambassador Tariq Fatemi once said, "the United States is held up as a country where freedom truly reigns. So therefore, the expectation is that Washington would also pursue freedom elsewhere. Sadly, it has not happened" (Fatemi, 2007) - especially in the case of Pakistan where it had been supporting the non-representative governments. As soon as General Ayub Khan imposed Martial Law in 1958, it was silently endorsed by the United States. Since then, the Americans feel it easy to deal with the military strongmen in the case of Pakistan than dealing with the democratic governments - a clear vindication of the US amoralism. US support for General Yahya Khan, General Zia-ul-Haq, and General Musharraf are the clear signs that upholding democracy lies somewhere down in the list of the US foreign policy priorities.

\subsection{Pakistan's Sovereignty: Drone Warfare and International Law}

US pursuance of amoralistic policies concerning Pakistan is also depicted in its violation of Pakistan's sovereignty, repeatedly in history. During some part of the Cold War, Pakistan had allowed the United States to use its airspace and certain bases to conduct surveillance of the Soviet Union specifically using the 
U-2 planes. The American U-2 aircraft that was shot down by the Soviet Union in 1960 took-off from Pakistan (Boyer, 2001, p. 791). Similarly, during 1980s Islamabad housed one of the biggest CIA field offices because of the American involvement in Afghan jihad. American CIA and Pakistan's ISI worked together to organise the guerrilla movement in Afghanistan. It was also the era when a dictator General Zia-ul-Haq was ruling Pakistan. These are the examples when Pakistan itself relegated some parts of its sovereignty to the United States and allowed it to operate from its land and use it as a base for the operations abroad. After $9 / 11$ attacks, the US not only violated several norms of international society, but also the moral principles for which it stands for. Fukuyama notes that, "was this outcome, in which the world's largest democracy undermined its own legitimacy as a bearer of democratic ideals, made inevitable by the lopsided distribution of power in the international system?" (Fukuyama, 2006). The debate revolved around certain questions, for example, whether is it legal/moral to fly drones in a foreign state violating its sovereignty? Secondly whether the target killing is justified? Whether militants fighting for their state have human rights as lawful combatants under the Geneva Conventions?

There is no denying the fact that any military strike conducted by state $\mathrm{A}$ in the territory of state $\mathrm{B}$ is considered as a violation of the sovereignty of the state B, especially when the state B has not requested such an action (Darnstadt, 2011). Use of drones in Pakistan's tribal areas had been one such 'amoralistic' act about which different international law experts have debated. Use of drones is against international law for many reasons: first, the violation of the sovereignty of a state. Although it has been claimed by certain scholars that sovereignty is not an absolute term, it is a relative term. Sovereignty is something that must be conceived not in the absolute terms of yes or no but in the relative terms of more or less (James, 1986, p. 207). Historically Pakistan had compromised certain parts of its sovereignty for the greater national interest; yet in this case Pakistan at different levels had not only criticised but protested the use of drones and violation of its sovereignty - but with no respite. "None of the United Nations Security Council resolutions on the fight against international terrorism, and in particular Al-Qaida, authorise the carrying out of operations on foreign territory, nor the arrest, and even less the killing, of (suspected) terrorists" (Ambos, 2011).

\section{Conclusion}

President Trump's four years in the White House has left a devastating impact on the American 'image' in the world (Baker \& Swanson, 2018; Burns, Baldor, \& Lee, 2019; Trump, 2018) - the same image which President Obama promised to build when he entered the White House. Because of the pursuance of the amoralistic policies, the US had even antagonised the realist intelligentsia which considers that the United States had parted company from realism on the issue of prudential considerations in the post-Cold War era (Mirza, 2016, pp. 169-171). It was considered as the undisputed leader of the 
free world since WW-II. Madeline Albright once noted "we have lost the element of goodness in American power, and we have lost our moral authority" (Madeleine Albright, as cited in Biel, 2011, p. 280). It will take a lot of time to repair the damage caused by President Trump. Yet the 'will' to restore the American 'lost image' will determine whether the United States will again gain the leadership role in the world. Loss of moral authority has forced the United States to face certain challenges, the most important being the two: First, since 9/11 it had been very difficult for the United States to find the much-needed allies in the wars it has launched since then. Even its age-old allies like France and Germany had shown resentment over its policies. Second, an image of the US being a lawbreaker has spread in the world. This image will create precedence for others to follow and may leave the world in a chaos. Whatever the critics say, amoralism will continue to be the defining characteristic of the American foreign policy generally and towards Pakistan specifically. US willingness to grant de jure membership to India of the Nuclear Supplier Group (NSG), de-hyphenation of Pakistan and India while neglecting the geopolitical sensitivities of the region, brushing aside the Indian activities in Afghanistan against Pakistan, and closing eyes on the human rights violations committed by India in Jammu and Kashmir, are few of the policies which it is pursuing in order to address its geopolitical grand designs - despite Pakistan's resentments. Moral principles, on the other hands, have always provided the United States - being the great power - a leverage to pressurise or entice Pakistan to do its bidding and in the case of failing, to use them as a tool to apply sanctions and distance from Pakistan.

\section{References}

Ambos, K. (2011, May 13). What International Law Says about the Killing of Bin Laden: Terrorists have Rights too. Spiegel Online. Retrieved from http://www.spiegel.de/international/world/0,1518,762417,00.html

Baker, P., \& Swanson, A. (2018, March 8). Trump Authorizes Tariffs, Defying Allies at Home and Abroad. The New York Times. Retrieved from https://www.nytimes.com/2018/03/08/us/politics/trump-tariffannouncement.html

Biel, R. (2011). The Entropy of Capitalism. Brill.

Billard Jr, R. D. (2010). Operation Cyclone: How the United States Defeated the Soviet Union. URJ-UCCS: Undergraduate Research Journal at UCCS, 3(2), 25-41.

Boyer, P. S. (2001). The Oxford Companion to United States History. Oxford University Press.

Brzezinski, Z. (1979, December 26). Memorandum for The President: Reflections on Soviet Intervention in Afghanistan. The White House.

Brzezinski, Z. (1980, January 2). Memorandum for The Secretary of State: Presidential Decisions on Pakistan, Afghanistan and India. The White House. 
Burns, R., Baldor, L. C., \& Lee, M. (2019, October 8). Trump defends decision to abandon Kurdish allies in Syria. Associated Press - AP NEWS. Retrieved from https://apnews.com/article/ac3115b4eb564288a03a5b8be868d2e5

Bush, G. W. (2001a). Address to a Joint Session of Congress and the American People. Speech, Washington D.C.

Bush, G. W. (2001b, September). President Bush: Today We Mourned, Tomorrow We Work, Remarks by the President upon Arrival. Presented at the South Lawn, The White House. The South Lawn, The White House.

Bush, G. W. (2002). The National Security Strategy of the United States of America. The White House.

Carr, E. H. (1964). The Twenty Years' Crisis, 1919-1939: An Introduction to the Study of International Relations. Harper Perennial.

Carr, E. H. (1999). The Twenty Years Crisis: 1919-1939. In M. Griffiths (Ed.), Fifty Key Thinkers in International Relations. Routledge.

Chambers, J. W., \& Anderson, F. (1999). The Oxford Companion to American Military History. Oxford University Press.

Chew, E. (2009). U.S. Foreign Policy and Southeast Asia: From Manifest Destiny to Shared Destiny. Newport, Rhode Island: William B. Ruger Chair of National Security Economics, U.S. Naval War College Press.

Copeland, M. (1970). The Game of Nations: The Amorality of Power Politics. Simon \& Schuster.

Council of Europe. (2008). CIA Above the Law?: Secret Detentions and Unlawful Inter-state Transfers of Detainees in Europe. Council of Europe Publishing.

Danner, M. (2009). US Torture: Voices from the Black Sites: Review of ICRC Report on the Treatment of Fourteen "High Value Detainees." The New York Review of Books. Retrieved from http://www.nybooks.com/articles/archives/2009/apr/09/us-torturevoices-from-the-black-sites/

Darnstadt, T. (2011, May 3). Justice, American Style: Was Bin Laden's Killing Legal? Spiegel Online.

Defense Intelligence Agency. (1985, December 7). Pakistan-China: Nuclear Weapons Production and Testing. US Department of State.

Desch, M. C. (2003). It is kind to be cruel: The humanity of American Realism. Review of International Studies, 29(03), 415-426.

Dunne, T., \& Schmidt, B. C. (2001). Realism. In J. Baylis \& S. Smith (Eds.), The Globalization of World Politics: An Introduction to International Relations. New York: Oxford University Press.

Dusza, K. (1989). Max Weber's Conception of the State. International Journal of Politics, Culture, and Society, 3(1), 71-105. JSTOR. Retrieved from JSTOR.

Eales, S. C. (2015). US Promotion of Democracy in the Post-Cold War Era. US Army War College. 
Elshtain, J. B. (2009, February). Realism, Ethics and U.S. Foreign Policy. Interview by Erik Owens presented at the Boston College. Boston College.

Fatemi, T. (2007, August). Ambassador Tariq Fatemi on Pakistani Politics after Lal Masjid. Presented at the Carnegie Endowment for International Peace. Carnegie Endowment for International Peace.

Ferguson, N. (2007). The War of the World: Twentieth-Century Conflict and the Descent of the West. Penguin Books.

Frost, M. (2012). Tragedy, Ethics and International Relations. In T. Erskine \& R. N. Lebow (Eds.), Tragedy and International Relations (pp. 21-43). Palgrave Macmillan.

Fukuyama, F. (2006). The Clash of Cultures and American Hegemony. The American Interest, 2(1).

Goldsmith, J. (2010, October 8). Don't Try Terrorists, Lock Them Up. The New York Times. Retrieved from http://www.nytimes.com/2010/10/09/opinion/09goldsmith.html

Hanke, E., Scaff, L. A., \& Whimster, S. (Eds.). (2020). The Oxford Handbook of Max Weber. New York, NY: Oxford University Press.

Harwood, J. (2017, August 16). Donald Trump has a very clear attitude about morality: He doesn't believe in it. $C N B C$. Retrieved from https://www.cnbc.com/2017/08/15/donald-trumps-morality-hedoesnt-believe-in-it.html

Hawley, C. (2010, October 11). The Legacy Battle: Bush-Schröder Enmity Continues in Memoirs. Spiegel Online. Retrieved from http://www.spiegel.de/international/world/the-legacy-battle-bushschroeder-enmity-continues-in-memoirs-a-728336.html

James, A. (1986). Sovereign Statehood: The Basis of International Society. Taylor \& Francis.

Joffe, J. (1992). Entangled Forever. In C. W. Kegley \& E. R. Wittkopf (Eds.), The Future of American foreign policy. St. Martin's Press.

Kaplan, R. D. (2011, August 15). The South China Sea Is the Future of Conflict. Foreign Policy.

Khan, L. A. (2014). Pakistan: The Heart of Asia. Speeches in the United States and Canada, May and June 1950 - by the Prime Minister of Pakistan. Harvard University Press.

Kissinger, H. A., \& Haig, A. (1970, December 9). Tape: Talk between Henry A. Kissinger and General Alexander Haig about South East Asia. The White House.

Kissinger, H. A., \& Nixon, R. (1970, December 9). Tape: Talk between Henry Kissinger and President Nixon about South East Asia. The White House.

Madar, C. (2012, October 3). Land of the ever less free. - Le Monde Diplomatique. Retrieved

from http://mondediplo.com/2012/10/03usjustice 
Mahmood, T. (1994). Pressler Amendment and Pakistan's Security Concerns. Pakistan Horizon, 47(4), 97-107.

Meernik, J. D. (2004). The Political Use of Military Force in US Foreign Policy. Ashgate Publishing, Ltd.

Mirza, M. N. (2014). American National Interest vis-a-vis Pakistan: A Retrospect. Pakistan Journal of American Studies, 32(2), 43-64.

Mirza, M. N. (2016). The Enduring Legacy of Realism: US Foreign Policy Behaviour in the Post-Cold War Era. Pakistan Journal of Social Sciences.

Model, D. (2008). State of Darkness: US Complicity in Genocides Since 1945. AuthorHouse.

Morgenthau, H. (1948). The Political Science of E. H. Carr. World Politics, $1(01), 127-134$.

Morris, B. S. (2015, April 27). Nixon and the Cambodian Genocide. Retrieved October 9, 2020, from Jacobin Mag website: https://jacobinmag.com/2015/04/khmer-rouge-cambodian-genocideunited-states/

Nelson, A. K. (2008). The Policy Makers: Shaping American Foreign Policy from 1947 to the Present. Rowman \& Littlefield Publishers.

Obama, B. H. (2006, November). Remarks of Senator Barack Obama, "A Way Forward in Iraq." Senator Speech presented at the Chicago Council on Global Affairs. The Chicago Council on Global Affairs.

Obama, B. H. (2009, December). Remarks by the President in Address to the Nation on the Way Forward in Afghanistan and Pakistan. President Speech presented at the Eisenhower Hall Theatre, United States Military Academy at West Point, West Point. Eisenhower Hall Theatre, United States Military Academy at West Point, West Point.

Ohaegbulam, F. U. (1999). A concise introduction to American foreign policy. Peter Lang Publishing.

Owen, T., \& Kiernan, B. (2006). Bombs over Cambodia. The Walarus, 62-69.

Paterson, T. (2006, October 25). German ministers "knew about CIA torture cells." The Independent. Retrieved from http://www.independent.co.uk/news/world/europe/german-ministersknew-about-cia-torture-cells-421491.html

Patrick, S. M. (2019, January 15). The Liberal World Order Is Dying. What Comes Next? World Politics Review. Retrieved from https://www.worldpoliticsreview.com/insights/27192/the-liberalworld-order-is-dying-what-comes-next

Priest, D., \& Gellman, B. (2002, December 26). U.S. Decries Abuse but Defends Interrogations. The Washington Post. Retrieved from http://www.washingtonpost.com/wpdyn/content/article/2006/06/09/AR2006060901356.html

Ripsman, N. M., Taliaferro, J. W., \& Lobell, S. E. (2016). Neoclassical Realist Theory of International Politics. New York: Oxford University Press. 
Rizwan Hussain. (2005). Pakistan And The Emergence Of Islamic Militancy In Afghanistan. Ashgate Publishing, Ltd.

Siddiqi, F. H., \& Mirza, M. N. (2021). Introducing International Relation: Concepts, Theories, Practices. Karachi: Oxford University Press.

Thucydides. (1840). Melian Dialogue: Sixteenth Year of the War-The Melian Conference-Fate of Melos. In C. F. Smith (Trans.), History of the Peloponnesian War: 431 BC. Cambridge: Harvard University Press.

Tim Dunne, \& Brian C. Schmidt. (2011). Realism. In John Baylis, Steve Smith, \& Patricia Owens (Eds.), The Globalization of World Politics: An Introduction to International Relations. Oxford University Press.

Trump, D. (2018, January 1). "Lies \& Deceit" tweet, 04:12 am. Retrieved September 20, 2020, from Twitter website: https://twitter.com/realDonaldTrump/status/947802588174577664

US Department Of State. (1950, April 3). Foreign Relations of the United States, 1950, The Near East, South Asia, and Africa, Volume V. US Government.

Retrieved from https://history.state.gov/historicaldocuments/frus1950v05/d837

Williams, B. G. (2011). On the trail of the 'Lions of Islam': Foreign fighters in Afghanistan and Pakistan, 1980-2010. Orbis, 55(2), 216-239. 